TRANSPORT

\section{London Street Crowds}

\section{from our Planning Correspondent}

C.AR commuting into central London seems to be on the increase again after signs in the past few years that the upward trend was being halted. According to the latest annual report from the London Transport Board (HMSO, $9 s 6 d$ ), the average number of cars entering the central area between 7 a.m. and 10 a.m. was 3,800 more in 1968 than in 1967, an increase of 5 per cent. While private cars represented 80 per cent of the total volume of wheeled traffic, they carried less than twofifths of the total number of passengers. Two-thirds of the cars carried only the driver, while more than four-fifths of the remainder had only one passenger. On the other hand, London buses carried 60 per cent of passengers entering central London by road while representing only a seventh of the volume of vehicular traffic. While there is continuing demand from the public for bus travel, people's journeys are being increasingly frustrated by traffic jams. In 1968, tho total mileage lost through traffic congestion totalled $2 \cdot 8$ million miles, representing 1.2 per cent of the total scheduled mileage. This loss compared badly with the 1967 figures although it was still 20 per cent below the 1966 level. The widespread delays, the report says, have nullified the effects of introducing shorter routes.

The number of passengers carried on the buses and the underground in 1968 was 2,601 million, about 39 million ( 1.5 per cent) less than in the previous year. The decrease, however, compares reasonably well with the annual drop of $3 \cdot 3$ per cent between 1956 and 1966 .

Plans for the future, which are being discussed with British Rail as part of a programme for railway develop. ment in the London area in the 1970s and on into the $1980 \mathrm{~s}$, include the possible construction of two new tubes-one crossing London from south-west to northeast which could absorb the Aldwych to Waterloo branch of the Piccadilly Line, and, the other, an extension of the Bakerloo Line to Camberwell Green and Peckham. These long-term proposals are in addition to the Fleet Line on which the board hopes to start work early in 1970, and the extension of the Piccadilly line to Heathrow airport, the construction of which, the board says, could start at very short notice.

The financial position of the board does not promise well for the proposed takeover of the London Transport by the Greater London Council. Although the board's deficit in 1968 was $£ 0.9$ million less than in 1967 , the deficit totalled $£ 10$ million. Receipts came to just over $£ 105$ million, an increase of $£ 2.6$ million over the previous year, but the higher fares introduced in August and September were "too little and too late" to avoid a loss before charging interest.

\section{MUSEUMS}

\section{More Popular than Ever}

TuE Manchester Museum, which manages successfully to cater for its university and civic audiences, seems to go from strength to strength. What other university museum in Britain can boast not only of a city corporation which matches pound for pound the money from the university chest but also of six consecutive years in which the number of visitors has increased? Last year, total attendances reached 190,000 , and the director says in the report for 1967-68 that attendances should exceed 200,000 this year.

Although there was nothing like the bicentenary of John Dalton to celebrate during the 1967-68 year, the museum maintained its tradition of special exhibitions of Jocal interest with a photographic display of the Formby nature reserve and, capitalizing on the wave of sentiment for the steam locomotive, an exhibition of photographs, models and documents illustrating the history of the local company, Beyer and Peacock, which built railway engines from 1854 until a few years ago. This exhibition was supplied by the curator of the Manchester Museum's new neighbour, the Manchester Museum of Science and Technology. One way and another, Manchester looks like being better served by its museums than any city outside London.

The teaching activities of the museum also flourish. At one end of the scale, nineteen school classes attended the museum each week of term, while university interest in the museum increases. It is not exclusively the stamping ground of the university taxonomic biologists and geologists-the professor of Latin is arranging to teach some classes in the rejuvenated classical gallery.

The museum has also managed to find more spacesome rooms in the basement of the physics department - to house its collection of bird skins, which has slowly been barricaded behind school class impedimenta as teaching activities have expanded. And even the museum's finances have improved; in place of last year's deficit of $£ 2,262$, it had a surplus of $£ 430$ this year, but there is still a total deficit of $£ 5,371$ to work off.

\section{Earth-Moon System?}

THe Leningrad astronomer Dr Nikolai Kozyrev has made another remarkable spectrographic observation of the Moon's vulcanism, according to Novosti. It purports to link earthquakes on. the Earth, particularly in the United Arab Republic and off the coast of Japan on March 31, with the venting of gases from the Aristarchus crater on the Moon on the following day (April 1). Dr Kozyrev is said to hold that this shows that the Moon "responded" to the earthquakes. Dr Kozyrev is also quoted as saying: "My investigations dealt with the Aristarchus crater. Two spectrograms of the inner slope of the crater (from its western side) showed an unusual red spot approximately one to two $\mathrm{km}$ across. Such things are already familiar to scientists. But after measurements of the spectrograms obtained by the Crimean observatory, it was established for the first time that this spot is the result of an escape of gases-molecular nitrogen and cyanic gas.'

\section{ROWETT INSTITUTE Nutritional Research}

The Rowett Research Institute in Aberdeen was founded in 1922 to encourage the then much nceded research into nutritional problems. The 1968 report, 